\title{
Rural Collective Economy, Township Planning and the Rural Revitalization Strategy -- Case Study for the Suburbs of Beijing City
}

\author{
Chen Xueyuan \\ Beijing Municipal Research Center for Rural Economy, Beijing, China
}

Email address:

chenxueyuan2012@126.com

\section{To cite this article:}

Chen Xueyuan. Rural Collective Economy, Township Planning and the Rural Revitalization Strategy -- Case Study for the Suburbs of Beijing City. Journal of Investment and Management. Vol. 8, No. 6, 2019, pp. 94-108. doi: 10.11648/j.jim.20190806.12

Received: February 1, 2019; Accepted: May 5, 2019; Published: January 9, 2020

\begin{abstract}
This paper explains the regularity of the evolution of rural collective economic system and the historical position of Township Planning as a new stage of rural economic system reform after the dual-level management system and people's communes. Accordingly puts forward that the reform of overall planning of villages and towns is the only way to implement the strategy of rural revitalization. That is to say, the development space of village self-help competitive system is already very limited. The joint venture among village-level collective economic organizations will reconnect the fragmented land property rights, realize the centralized and optimized allocation of land resources, and promote the balanced and coordinated development of urban and rural areas and regions. The overarching principles for Township Planning has been elaborated, mainly include establishment of township-level cooperatives, spatial planning adjustment and layout optimization, property rights certification and development of diverse market entities, bank loans and private capital, optimization and standardization of quotas, equal rights to land and balanced development, industrial upgrading. The implementation measures and supporting policies and mechanisms are analyzed and combed, mainly includes intensive use of collective construction land, establishment of a modern industrial organization system for agricultural activities, and establishment a District-level Rural Collective Assets Supervision Commission. The above methods are known as the "three strategies for Township Planning." From the perspective of urbanization, the overall planning of towns and townships is transformed from urbanization mode driven by big cities to local urbanization.
\end{abstract}

Keywords: Rural Collective Economy, Township Planning, Rural Revitalization

\section{Introduction}

Since the $16^{\text {th }}$ National Congress of the Communist Party of China (CPC) which proposed the strategy of urban and rural planning, the balanced development of urban and rural areas and different regions across the country has become the theme of the times. The report to the $19^{\text {th }}$ CPC National Congress pointed out that what China now faces "is the contradiction between unbalanced and inadequate development and the people's ever-growing needs for a better life." [1] It also laid down a strategic plan to revitalize the countryside so that farmers can enjoy the benefits of urbanization that occurs near them. Rural collective economy is the most important component of China's rural economy and the economic basis for implementing the rural revitalization strategy.
General Secretary of the CPC Central Committee Xi Jinping has always attached great importance to the development of collective economy, stressing that the focus of poverty alleviation efforts should be on building up the capacity of township- and village-level rural collective economic organizations and calling rural collective economic organizations the "spearhead" of the transition to a market-based agricultural economy. [2-3] He has contributed to systematic theoretical discussions on a plethora of topics related to rural collective economic organizations, including but not limited to their philosophical foundation, functions, development path, and institutional reform, as well as social transition, poverty alleviation, culture and traditions, and Party leadership. [4] Xi's ideology of collective economy is proved by the exploration of the suburbs of Beijing where 
local authorities have been promoting the development of rural collective economic organizations through Township Planning. The overarching principles for Township Planning have been set out in the new urban plan of Beijing, providing important institutional support for the implementation of the rural revitalization strategy in the new era.

\section{Method}

The main methodology of this paper is based on historical materialism: social contradictions determine social nature, social nature determines objects of reform, objects of reform determine tasks of reform, tasks of reform determine motives and allies of reform, and then determine nature of reform, which is concretely translated into routes, policies and policies of reform. [5] In this way, a model of economic system evolution can be established. The essence of putting forward the idea of overall planning reform in villages and towns is to demonstrate the laws and stages of the evolution of rural economic system.

After leaving the age of drinking blood, human beings began to settle down in pastoral style. We must solve three basic problems: what to produce, how to produce and for whom to produce. We need to deal with the allocation relationship among the three elements of labor, land and capital, the property right relationship between the elements occupying and operating subjects, and the regulatory relationship between micro-subjects and macro-management. Different stages of historical development are facing different major social contradictions, showing different modes of production, which determine the corresponding social nature and social form, and form the corresponding economic system.

The concept of economic system can be large or small. It can be aimed at a country, a province, a county, a village or even a farmer. However, the goal, superstructure, mechanism and subject are the four basic elements. The goal is the general values, which commands the other three aspects. The other three aspects will change sooner or later. For example, in ancient China, solving floods was the most important goal at that time. Gong passively slackened his work and used blockage to manage water. He was banished to death after seven years of inactive work. Dayu crossed his family but did not enter for three times. He succeeded in running water by dredging and was elected tribal leader. The essence of economic system is a logic of development under the guidance of the first objective, which is a "omnipotent" key to understanding the historical changes of human society economic system. [6]

\section{Historical Position of Township Planning: A New Stage in the Evolution of China's Rural Collective Economic System}

Since the agricultural co-operative movement in the 1950s, the rural economic system in the suburbs of Beijing has undergone three-stage evolution: from a three-tiered people's commune system, the basic unit of which is a production team, to a two-tiered rural household contract management system which consisted of two types of actors, namely, collective economic organizations and rural household contractors, to a compound rural economic system.

\subsection{Stages in the Evolution of the Rural Collective Economic System}

(1) Stage I: the people's communes (1958-1977). Stage I can be further divided into the following phases: (i) Establishment of a collective property rights system. In the 1950s, the suburbs of Beijing underwent a cooperative movement, and built high-level communes within which land and agricultural machinery and tools were not included in dividends allocation. (ii) Establishment of the basic organizational structure of the people's communes. In 1962, the central government promulgated the Sixty Articles on the People's Commune. According to the decision made by the central government, Beijing downsized the people's communes, created lower-level accounting units, and established a stable three-tiered people's commune system with the production team as its basic unit. During this period, the main goal of rural economic reforms was to supporting the national industrialization construction, and the collective economy struggled for slow progress under stringent control.

(2) Stage II: a two-tiered management system (1978-2001). At this stage, the rural economic system has evolved into a two-tiered rural household contract management system which consisted of two types of actors, namely, collective economic organizations and rural household contractors. This stage can be further divided into two phases. (i) Phase I - establishment of basic rural economic entities (1978-1991): The Third Plenary Session of the $11^{\text {th }}$ CPC Central Committee was the prelude to rural reform which included two stages: labor contracted to production teams and then to households. The reform granted rural households autonomy over production and operation, and managed to solve the subsistence problem in no time. On this basis, the government started to reform the people's communes which had both governmental and economic functions, and explored moderate-scale land operation, and as a result, township enterprises sprung up. (ii) Phase II market-oriented reform (1992-2001): The $14^{\text {th }}$ CPC National Congress laid down a plan to transition to a socialist market economy. A market-oriented reform was carried out in the suburbs of Beijing to improve economic efficiency. Efforts were made to reform the rural collective property rights system, develop the hybrid economy, reform the agricultural product distribution system, adjust administrative divisions at the town level, and reform township- and village-level institutions. 
(3) Stage III: a compound economic system (2002 till now). Due to the dual urban-rural system and widening internal disparities with China's countryside as a result of uncoordinated development, the urban-rural divide and regional inequality have emerged as a major problem in the country. In 2015, there were 311 insolvent village-based collective economic organizations in Beijing, accounting for $7.8 \%$ of the total number of village-based collective economic organizations in the city; 1,717 village-based collective economic organizations in Beijing reported a net loss, accounting for 43.3\%. In 2014, there were 12 village-based collective economic organizations in Shijingshan District as an urbanized area. Among them, five reported a net profit, four broke even, and three reported a net loss, showing that there were internal disparities even within completely urbanized areas. A study of the changes in the total income of 40 villages $^{1}$ in the suburbs of Beijing from 1978 to 2014 shows that the income distribution pattern (high income/middle income/low income) among these villages has been solidified. [7] To break the solidified pattern and promote the balanced development of rural areas in the suburbs of Beijing, it is necessary to drive the development of small towns, advance the "Beautiful Countryside" campaign, and accelerate the equal access to social security and public services in urban and rural areas. Townships are places where population and industrial activities gather. They hold the key to the solution of the unbalanced development problem. Dongsheng Town, Xihongmen Town, Cuigezhuang Township and Lugouqiao Township have carried out a series of reforms and experiments. A new compound economic system that promotes coordinated development of villages, townships and districts has come to the fore.

Table 1 shows the evolution path of Beijing's rural collective economy system.

\subsection{Development Path of the Rural Economy}

The economic system of a society is defined by the major economic challenges it faces. The thrust of China's rural economic reform is to make changes to the management system of the agriculture sector and rural areas to ameliorate problems and address challenges faced by the economy and society in each period.

The rate of urbanization of Beijing has hovered over 70\% since 1990 , and climbed to over $80 \%$ in 2005 . In $2010-2017$, it fluctuated within a very narrow range (86\%-86.5\%). In 2005-2017, the permanent rural population in China stopped the downward trend and rebounded from 2.51 million to 2.94 million. This means that the large-scale migration from rural areas to urban areas has ended, and functions and economic

1 The selection of village samples is obtained by stratified sampling method. First, ensure that each district has village samples, and then select specific village samples in each district. activities of central cities are moving to the suburbs. However, since the disintegration of the people's communes and the establishment of the household contract management system, the evolution of the rural economic system has failed to align to this trend. Currently, China has three major rural economic systems: (i) a two-tiered system which combines both individual and village-level collective production; (ii) a system under which the village-level collective economic organization does not perform any de factor functions and rural economic functions are performed by rural households; (iii) a system under which agricultural land is transferred to private entities or large farms whereas the village-level collective economic organization exists in name only. After the township-level compound economic system took shape, the government began to put in place effective institutional mechanisms, seeking to promote urban and rural integration, integrate agricultural modernization with rural industrialization and urbanization, eliminate absolute poverty and relative poverty, realize common prosperity, and support the implementation of the rural revitalization strategy in Beijing and across the whole country.

\subsection{Typical Models of the Compound Economy}

(1) Land joint-stock cooperatives: featuring collective ownership and a two-tiered management structure. Land joint-stock cooperatives are often created in villages with few assets in collective accounts but a lot of land resources. Under a land joint stock cooperative arrangement, farmers pool their clearly defined land use rights which are granted to them through a contract with the state to engage in cooperative agricultural production. They are then given a share of the joint-stock cooperative which is converted from the original village-level collective economic organization. The cooperative is responsible for unified land management and production planning within the village. Since the Central Committee promulgated the Guidelines for Steadily Promoting the Reform of the Rural Collective Property Rights System, most villages, in the face of operational assets shortages, have established land joint-stock cooperatives as part of the reform of the collective property rights system. Such villages include Tangyue in Guizhou Province (see Figure 1) and Majigou and Zhaojiamao in Shanxi Province. [8] In mountainous areas, some villages allocate shares of a joint-stock cooperative which is created to manage the land and resources on the collectively-owned mountain to the members of the cooperative. Such villages include Huayuan and Taoyuan Valley in Miyun District of Beijing.

(2) Village-run companies with villagers as the investors: featuring a two-tiered ownership structure and a multi-layer management structure. A village which sees great potential in a project but lack funds to expand the project may create a joint stock company and encourage villagers to make cash or in-kind contributions to the company. The village-level economic organization 
holds the collective shares of the company, which are issued based on the collective assets of the village accumulated over the years. Some villages have co-funded joint-stock companies with corporate and individual investors. Such villages include Beilangzhong Village in Shunyi District, Beijing (see Figure 2), and Yuanjia Village in Xianyang City, Shaanxi Province.

(3) Converting existing collective assets into shares and allocating them to villagers: collective ownership and unified management. This reform is suitable for rural collective economic organizations with abundant assets in the collective account and realizes the transition of common ownership of assets collectively owned by a village to shareholding by individual villagers. Most villages in economically developed areas of eastern China have adopted this reform. Currently, the reform of the township-level collective property rights system in Beijing is focused on the areas within the first and second green belts, spreading from the inner suburbs to the outer suburbs. It has been completed in the Songjiang District of Shanghai. There are three ways to do so: (i) covert the collective net assets into shares and directly allocate the shares to members of the collective economic organization, as is the case with the cooperative of Xinqiao Town, Shanghai; (ii) convert part of the collective assets into shares and allocate a share to every member of village-level collective economic organizations within the jurisdiction, and allocate the remaining assets (converted into shares) to members working at the township-run collective enterprise, as is the case with Dongsheng Town, Beijing; (iii) convert all of the collective assets into shares and allocate a share to every member of village-level collective economic organizations within the jurisdiction, including members working at the township-run collective enterprise, who receive shares from the village where their hukou is registered, as is the case with Shijingshan District (see Figures 3 and 4).

(4) Township-level economic organizations: featuring a three-tiered ownership structure and a multi-layer management structure. Under such an arrangement, a cross-village economic organization is established to achieve centralized management of land collectively owned by villages, as well as economic upgrading. Farmers within the jurisdiction may participate in the organization by leasing their land to or making cash or in-kind contribution to the organization which features a two-tiered ownership structure and a multi-layer management structure. (Figure 5).

Table 1. Evolution of the rural collective economy system in Beijing.

\begin{tabular}{|c|c|c|c|c|}
\hline & \multirow{2}{*}{$\begin{array}{l}\text { Stage I: the } \\
\text { people's communes } \\
(1958-1977)\end{array}$} & \multicolumn{2}{|c|}{ Stage II: a two-tiered management system (1978-2001) } & \multirow{2}{*}{$\begin{array}{l}\text { Stage III: a compound } \\
\text { economic system }(2002 \text { till } \\
\text { now) }\end{array}$} \\
\hline & & $\begin{array}{l}\text { Establishment of basic rural economic } \\
\text { entities (1978-1991) }\end{array}$ & $\begin{array}{l}\text { Market-oriented reform } \\
(1992-2002)\end{array}$ & \\
\hline $\begin{array}{l}\text { Strategic } \\
\text { goals }\end{array}$ & $\begin{array}{l}\text { Supporting } \\
\text { industrialization }\end{array}$ & Addressing subsistence demands & Boosting efficiency & $\begin{array}{l}\text { Achieving balanced } \\
\text { development }\end{array}$ \\
\hline $\begin{array}{l}\text { Supporting } \\
\text { policies }\end{array}$ & $\begin{array}{l}\text { Expenditure on } \\
\text { inputs of the people's } \\
\text { communes was } \\
\text { covered by the } \\
\text { government. }\end{array}$ & $\begin{array}{l}\text { The central government issued the No. } 1 \\
\text { Document to endorse the development of } \\
\text { the people's communes. It also increased } \\
\text { the purchase prices of agricultural } \\
\text { products, promoted the development of } \\
\text { suburban agriculture and moderate-scale } \\
\text { farming. The government also issued the } \\
\text { Notice on Promoting the Development of } \\
\text { Rural Cooperatives and Collective } \\
\text { Economic Organizations. }\end{array}$ & $\begin{array}{l}\text { The government supported the } \\
\text { industrialization of agriculture, } \\
\text { established an agricultural service } \\
\text { system, deregulated the } \\
\text { circulation of agricultural goods, } \\
\text { promoted the development of six } \\
\text { sub-sectors of agriculture, } \\
\text { reformed township enterprises, } \\
\text { and supported the development of } \\
\text { manufacturing yards. } \\
\text { Transition from planned }\end{array}$ & $\begin{array}{l}\text { The government took measures } \\
\text { to support the development of } \\
\text { modern agriculture in urban } \\
\text { areas, establishment of a } \\
\text { modern rural property rights } \\
\text { system, advancement of the } \\
\text { "New Countryside" campaign, } \\
\text { equal access to basic public } \\
\text { services, and implementation of } \\
\text { the rural revitalization strategy }\end{array}$ \\
\hline $\begin{array}{l}\text { Resource } \\
\text { allocation }\end{array}$ & Planned allocation & $\begin{array}{l}\text { Transition from planned allocation to } \\
\text { market-based allocation }\end{array}$ & $\begin{array}{l}\text { allocation to market-based } \\
\text { allocation; development of } \\
\text { product markets; development of } \\
\text { the markets of factors of } \\
\text { production and property rights }\end{array}$ & $\begin{array}{l}\text { Transition from planned } \\
\text { allocation to market-based } \\
\text { allocation; growth of rural } \\
\text { property rights markets }\end{array}$ \\
\hline $\begin{array}{l}\text { Supporting } \\
\text { mechanisms }\end{array}$ & $\begin{array}{l}\text { The people's } \\
\text { communes are in } \\
\text { essence large-scale } \\
\text { public organizations, } \\
\text { featuring a } \\
\text { three-tiered structure } \\
\text { under which the } \\
\text { basic unit was a } \\
\text { production team. }\end{array}$ & $\begin{array}{l}\text { Measures put in place to promote quota- } \\
\text { or phase-based contracting, link } \\
\text { renumeration of teams/farmers to output, } \\
\text { implement the household-based } \\
\text { contracting (da baogan) system, and } \\
\text { improve rural level-two cooperative } \\
\text { economic organizations }\end{array}$ & $\begin{array}{l}\text { The basic economic system with } \\
\text { public ownership playing a } \\
\text { dominant role and different } \\
\text { economic sectors developing side } \\
\text { by side; reform of township- and } \\
\text { village-based enterprises; reform } \\
\text { of the rural collective property } \\
\text { rights system }\end{array}$ & $\begin{array}{l}\text { Collective economic } \\
\text { organizations, specialized } \\
\text { cooperatives, family farms, } \\
\text { leading enterprises and other } \\
\text { new rural economic entities; } \\
\text { reform of the governance } \\
\text { structure of rural collective } \\
\text { economic organizations; } \\
\text { coordinated management of } \\
\text { collective construction land in } \\
\text { villages and townships }\end{array}$ \\
\hline
\end{tabular}



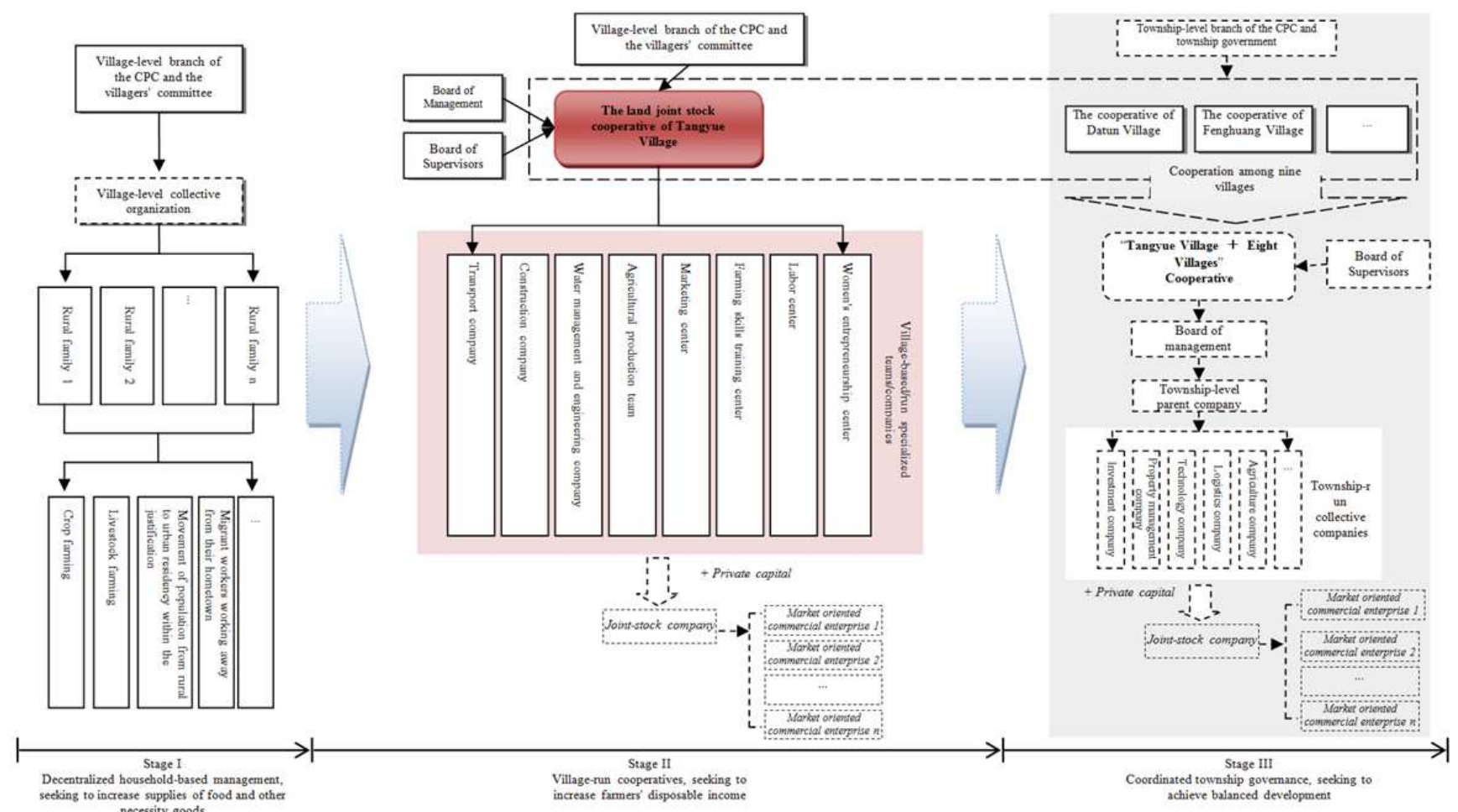

Figure 1. Evolution of the collective economy of Tangyue Village.
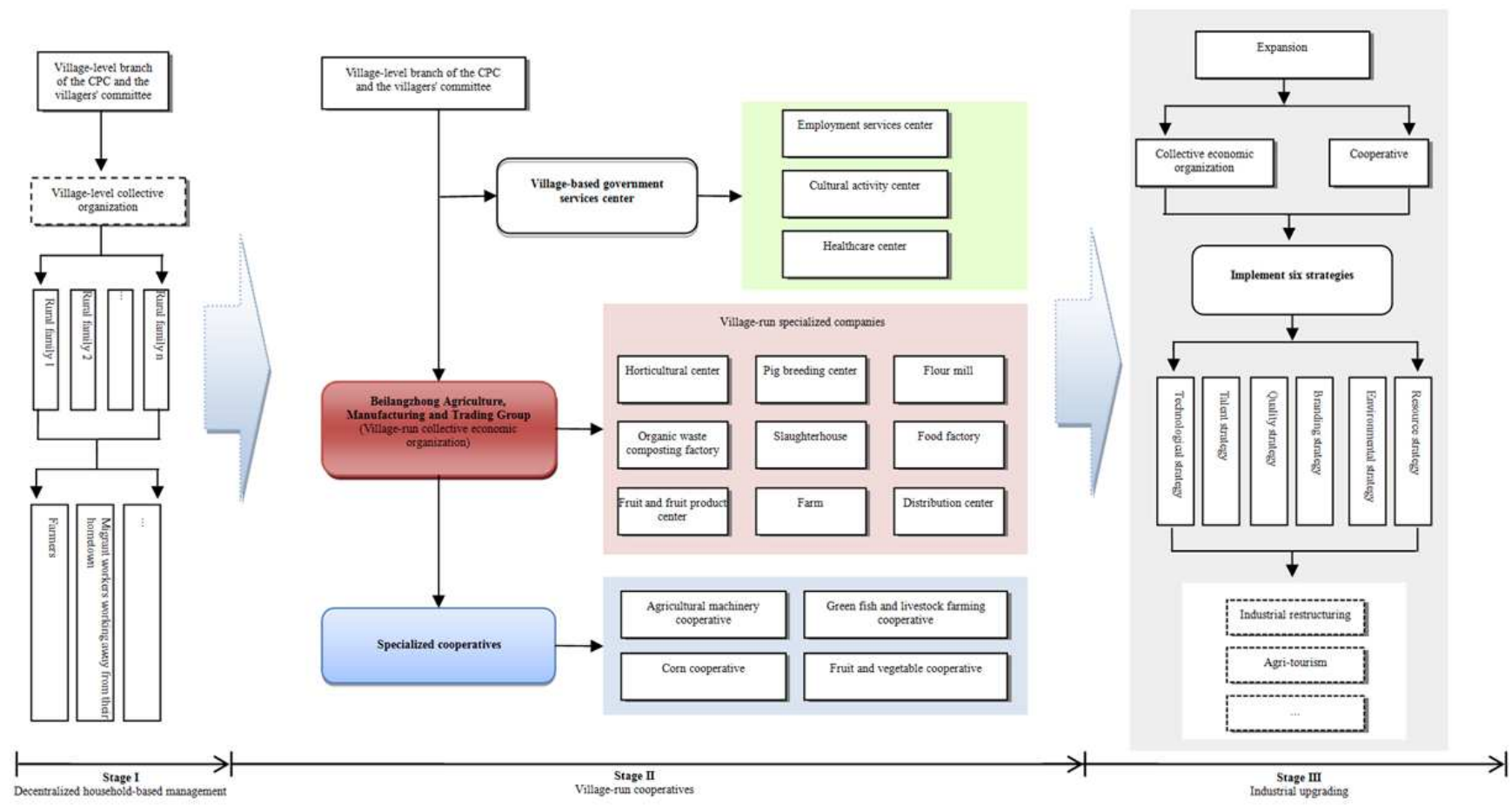

Figure 2. Reform of the economic system of Beilangzhong Village. 


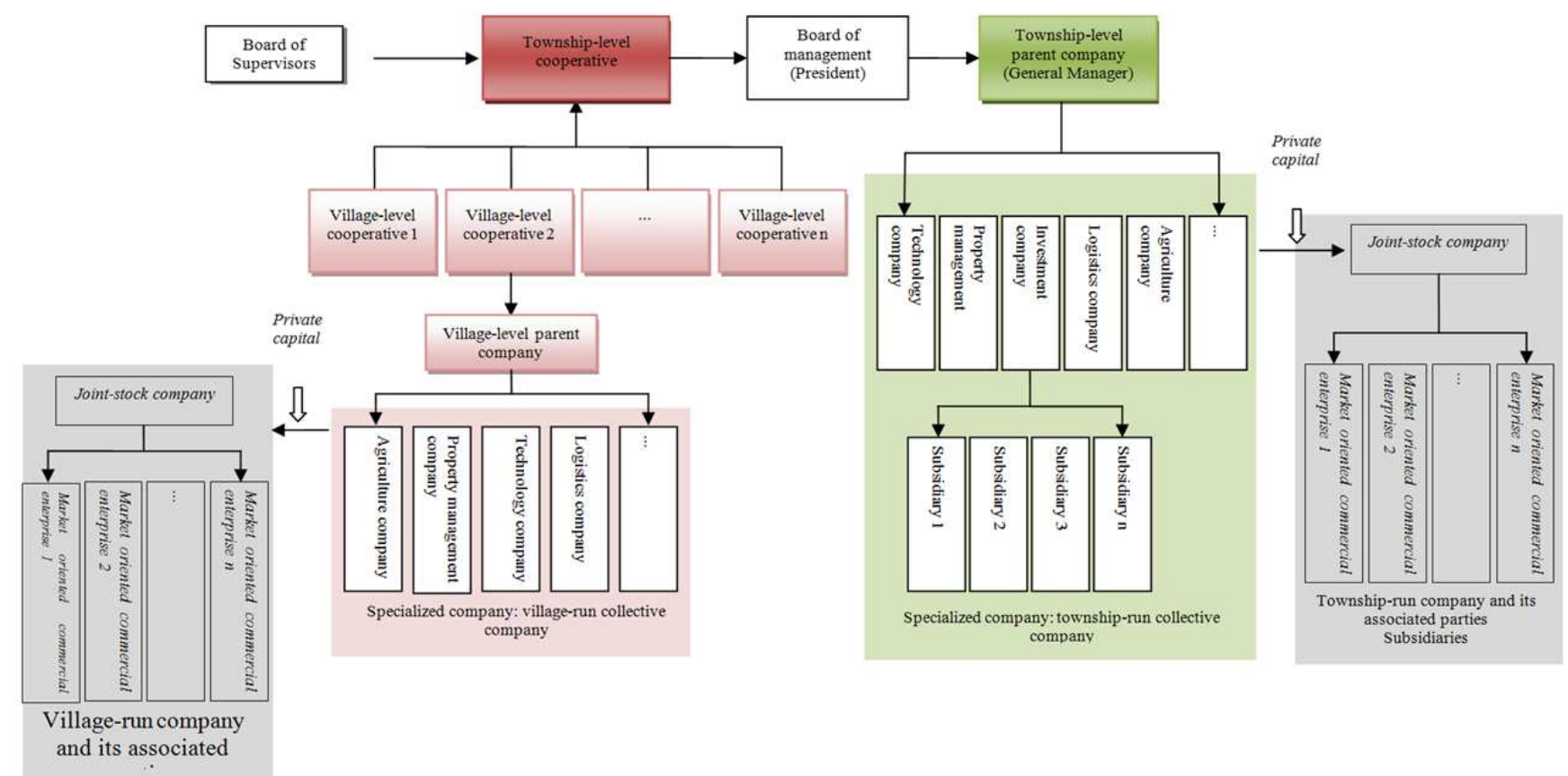

Figure 3. Structure of a rural collective economic system featuring a two-tiered ownership structure and a multi-layer management structure in the context of Township Planning (Cooperative).

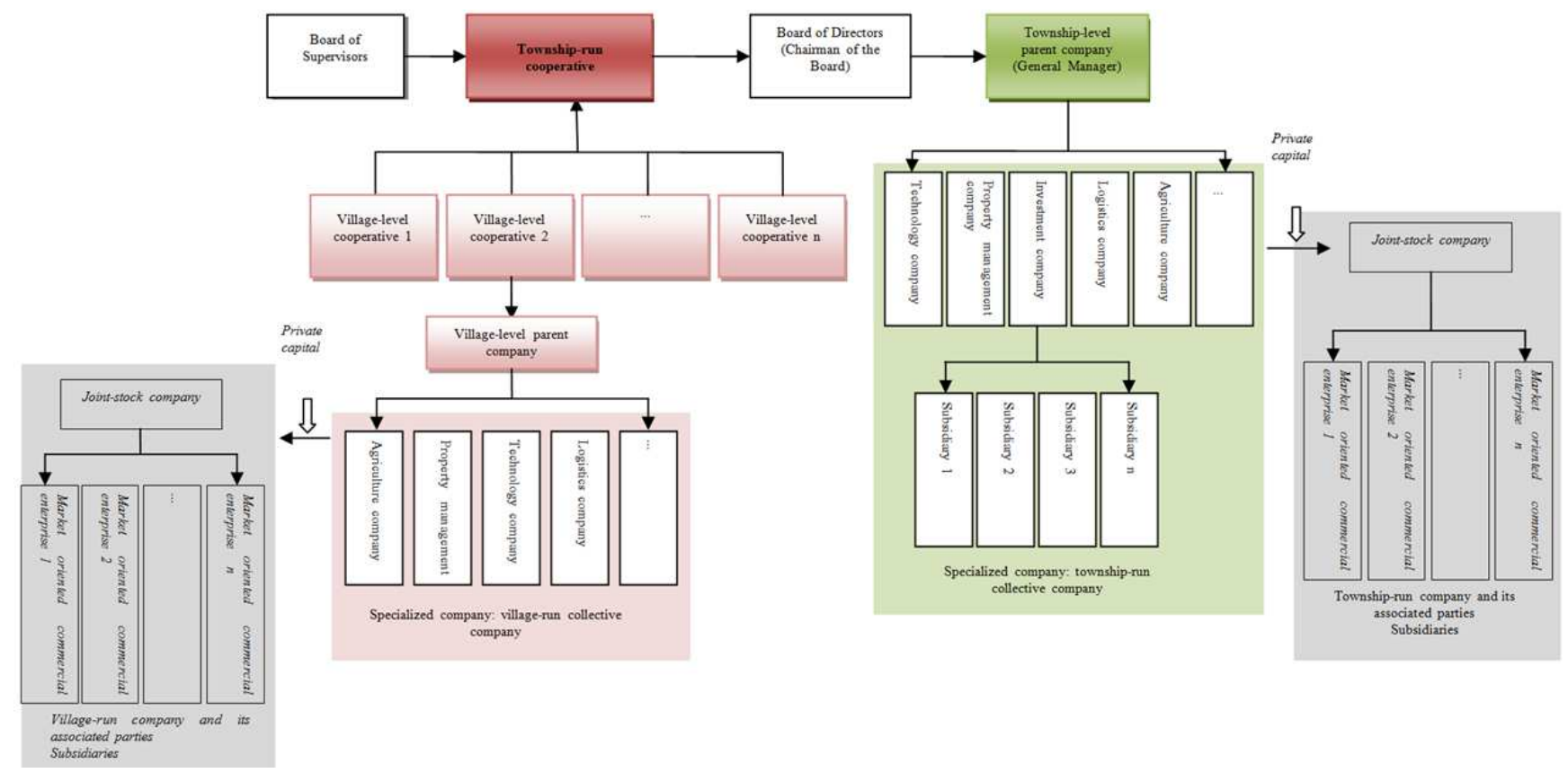

Figure 4. Structure of a rural collective economic system featuring a two-tiered ownership structure and a multi-layer management structure in the context of Township Planning (Company). 


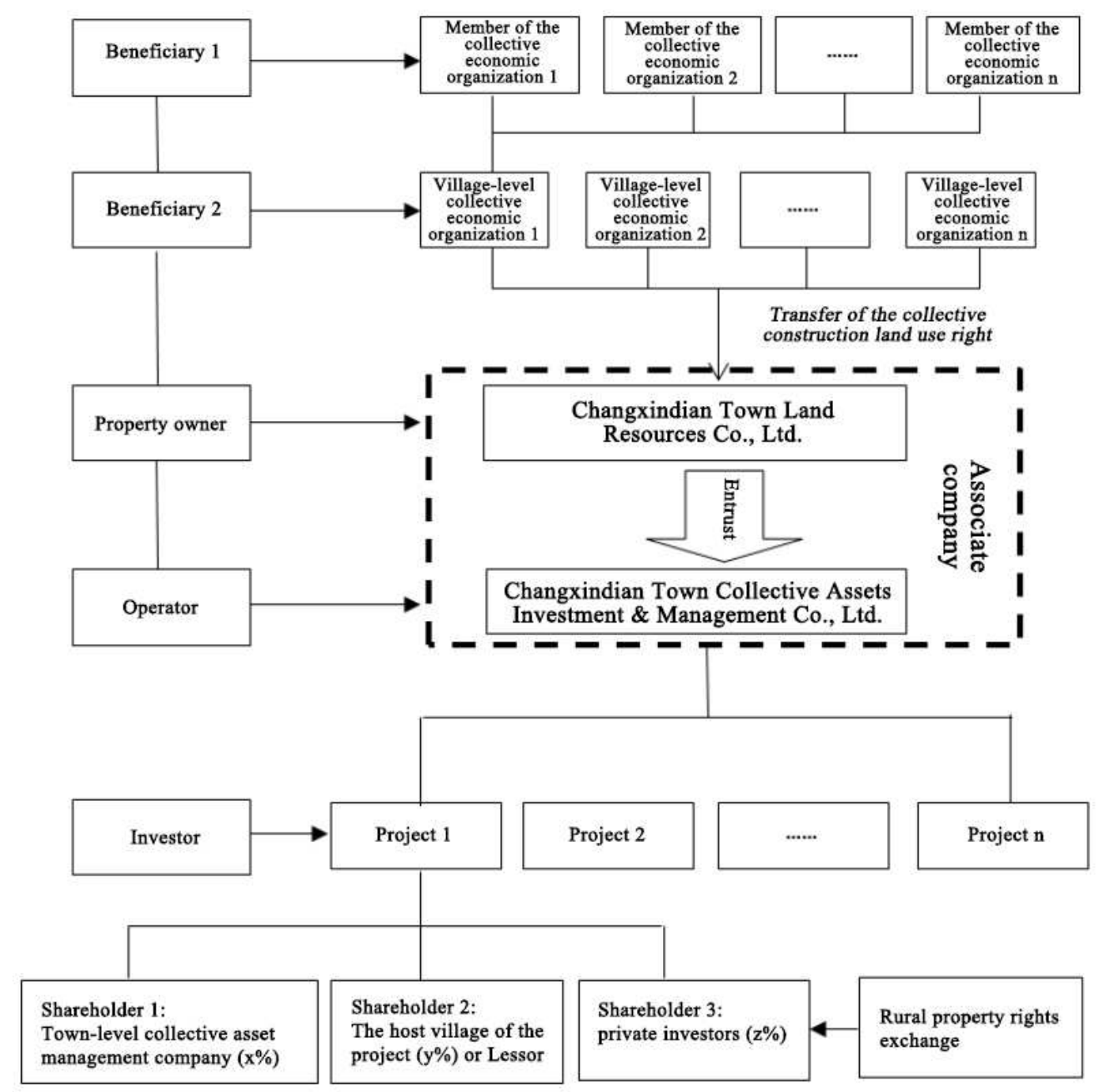

Figure 5. Organizational structure of the collective land management cooperative in Changxindian Town.

\section{Township Planning}

The fact that township-run economic organizations often remind people of the people's communes which are in essence large-scale public organizations is in itself a cause of concern. They are often associated with irrational centralization and re-allocation of collective assets at the same level. Scientifically and rationally designing the governance boundaries of township- and village-level collective economic organizations, clearly defining property rights, improving the corporate governance structure, strengthening external supervision, and improving policy mechanisms are the key to the success of Township Planning. Generally speaking, according to the Reform Experience of Daxing District, township planning can be achieved through (i) establishment of a township cooperative organization tasked with the responsibility of converting collective land into shares and centrally managing land within the jurisdiction of the township, as is the case with "inter-village joint ventures", or (ii) planning by the government which can use administrative means to coordinate planning and promote balanced development within the township, as is the case with "district/township planning." [9]

\subsection{Planning Methods}

(1) Township-level planning. For example, Xihongmen Town has coordinated the planning of collective construction land; Cuigezhuang Township has established a land cooperative; and Dongsheng Town has reformed its township-level collective property rights system;

(2) District-level planning. For example, Jiugong Town has divided 19 villages into four districts and set up a township-level cooperative which then created a branch for each district. District-level planning is much easier to achieve than the planning of an entire township, and district-level cooperatives are in fact equivalent to township-level cooperatives under the township-level planning model;

(3) Project-level planning. Laiguangying Township, Chaoyang District, has achieved Township Planning by establishing a joint stock township cooperative organization, whose shares are held by rural collective economic organizations. The township and villages within the jurisdiction of the township jointly invest in real estate projects through the cooperative organization 
which pays dividends to the shareholding villages. Take the public works project in the C9 Plot, Lugouqiao Township for example. A joint venture was created to coordinate resources from six villages, including villages which boast good locations but don't have planned construction land quotas, those with quotas but without ideal locations, and those with sufficient funds, as well as from the township-level parent company.

In general, the choice of planning method is mainly influenced by the local conditions of the town, planning premises, and resources to be coordinated.

\subsection{Township-level Entities}

(1) Decision-making entity. The decision-making entity is mainly responsible for making major decisions and coordinating stakeholders. It plays a central role in the Township Planning system. A township may establish a steering group led by the secretary of the township Party committee. The steering group will meet to decide on major issues such as large-scale investment and appointment and dismissal of important personnel. The township Party committee is primarily responsible for coordinating the work of all relevant departments and urging the village Party branches to advance relevant plans.

(2) Management entity. The management team is led by the mayor or deputy mayor of the township and made up of specialists who understand both the grassroots-level situation and higher-level policies, as well as insiders capable of coordinating with different departments. The team is mainly responsible for managing administrative affairs related to Township Planning, developing and adjusting work plans, coordinating and unifying policies, setting standards (in relation to land shares, demolition, construction, industry access, etc.), funding infrastructure projects and providing specialized services to support the operation of the township cooperative or joint venture.

(3) Property owner. The township-level land management cooperative or joint venture is the property owner, which is the core of township entities. The use rights of collective construction land are transferred from villages to the township-level land management cooperative or joint venture which is responsible for unified land management and pays dividends to shareholders. The township-level land management cooperative or joint venture is at the heart of the township-level planning system. It will become more and more specialized as the economy grows, and eventually form a township-level planning system featuring a two-tiered ownership structure and a multi-layer management structure. At the township level, a collective construction land joint-stock cooperative and an agricultural land joint-stock cooperative can be set up to manage construction land and agricultural land, respectively. Township-level land management cooperatives or joint ventures should improve their corporate governance structure and internal operational mechanisms, and step up risk control.

(4) Operator. The township collective asset management company is the operator of the collective assets. To facilitate market-oriented operation, the township-level land management cooperative, without the status as a full market player, entrusts the use rights of collective construction land to the township collective asset management company which is responsible for, among others, building dismantling, project initiation, construction, and loans/mortgages, etc.. In practice, a joint venture is usually created to assume the functions of both the property owner and the operator and to achieve market-oriented operation.

(5) Investor. The township collective asset management company and the project partner (s) set up a joint venture for investing. The joint venture is responsible for completing the project application process as well as the development and construction of the project. The village where the project is located can also be an investor.

(6) Beneficiaries. The members of the village collective economic organization are the beneficiaries. After the reform of the collective property rights system, the income generated from collective construction land will be distributed to them in the form of dividends.

(7) Democratic resolution subjects. Democratic procedures are put in place to allow members of the collective economic organization to participate in decision-making. Such democratic mechanisms include the township-level people's congress and the village-level meetings of shareholders and members of the collective economic organization.

\subsection{Ownership Structure}

Shares are given based on the land use right contribution of shareholders or its consideration. The ownership structure reflects the relationship between shareholders and decision-making and management mechanisms. In practice, the contribution of shareholders can take the form of collectively owned capital, creditor's rights, land, or population-linked construction land quotas.

(1) Pooling of collective assets. When collective assets are coordinated, the shares are issued to shareholders based on the collective assets contributed by them. For example, the township-level collective economic organization of Dongsheng Town, Haidian District, issued collectively held stocks and stocks for individual members. Stocks for individual members are further divided into basic stocks, resource-based stocks and years of service-based stocks.

(2) Pooling of construction land quotas. Under this arrangement, shares are given to shareholders based on their construction land quotas. In practice, shares are often given based on population-linked construction land quotas or simply construction land quotas. In the 
meantime, cash contribution is also allowed. Shareholders may make cash or in-kind (land quotas) contribution or a combination of both. Each member or unit of land corresponds to a share.

For example, Jiugong Town has coordinated population-linked construction land quotas. The construction land quotas received by Villages No. 1, No. 2, No. 3 and No. 4 in the Nanjie Neighborhood for reconstruction of an industrial yard were used to construct the 'Sunlon ' Zhongke' E-business Valley. In order to coordinate stakeholder interests, the four villages set up a joint venture. The number of shares held by each village was determined based on their respective population. The contribution of each villager is the same which means all villagers have the same rights to benefits. The proportion of shares held by each village is equal to the ratio of its population to the combined population of the four villages.

The township-level joint venture of Xihongmen Town issues shares to the village-level economic cooperatives based on the size of land. The legal persons of the cooperatives serve as shareholder representatives and participate in decision-making and management of the joint venture. The secondary distribution of net profit takes place after the guaranteed income of villagers is distributed. Shareholders may make contributions at any time. So far, all village-level collective economic organizations within the jurisdiction of the town have made contributions to the joint venture which issues shares to village-level collective economic organizations in proportion to their respective land use rights. The contributed land use rights are determined based on the measured size of land.

The Lanfa Group of Huangcun Town allows shareholders to make both cash and land contribution. Although all village-level collective organizations have chosen to make cash contribution, it is stipulated in the company's articles of association that "the proportion of shares held by each shareholder (i.e., shareholding village-level collective organizations) shall be equal to the ratio of the size of land entrusted by the shareholder to the total area of land entrusted by all shareholders."

(3) Pooling of funds, locations and planned land quotas

The hybrid planning method refers to the method used by a township-level joint venture to determine the equity ratio of its shareholders based on their contributed capital, land, and planned land quotas. This method is often adopted in highly urbanized areas where rural collective economic organizations generally have a deep pocket and a large number of high-end industrial projects but are facing land shortages.

Take the public works project in the C9 Plot, Lugouqiao Township, Fengtai District for example. The project is located near the Lize Bridge, a prime location. However, the planned use of the site is green space. Lugouqiao Township coordinated resources, including planned land quotas, locations and funds, from surrounding areas to support the development of the project. The number of shares held by shareholders is determined based on the proportion of the building area contributed by them.

\section{Supporting Policies and Mechanisms for Township Planning}

Township Planning allows farmers to engage in urbanization in an organized way and drive the transformation of the rural social structure. To achieve Township Planning, it is necessary to (i) promote the intensive use of collective construction land in areas of concentrated urbanization, and support high-end industrial projects; (ii) establish a modern industrial organization system for agricultural activities in areas of non-concentrated urbanization; and (iii) establish a rural collective assets supervision commission which should be responsible for monitoring collective economic organizations and companies, improving collective asset management, providing institutional support for agricultural and rural modernization, and promoting district-level assets pooling. The above methods are known as the "three strategies for Township Planning."

\subsection{Intensive Use of Collective Construction Land}

The biggest challenge faced by China in the implementation of the rural revitalization strategy is the shortage of planning construction land resources, as reflected in the fragmentation of land property rights. It is necessary to put in place a new collective land planning and management system for rural areas. [10]

At the core of the system should be balanced township development.

(1) Establishment of township-level cooperatives

The task at this stage is to establish a cross-village joint venue to serve as the property owner. The village collective organizations transfer collective construction land owned by them to the town-level joint venture which issues shares, and pays dividends to each village and protects the rights of the shareholding villages to participate in its decision-making and supervise its operation. The cooperative can join hands with private investors to set up a new company for investing. However, the control must be in the hand of farmers and rural collective organizations in principle. Private investors shall not be given the ownership of construction land or directly exercise the land use right of construction land.

(2) Plan adjustment and layout optimization

Land use approval is essential for Township Planning. The land use plans of villages should be adjusted to ensure optimal land use in accordance with urban development and land development planning principles. The district-level approval process for use of lands in villages should be improved to provide institutional support for standardized development and utilization of collective construction land. In terms of spatial layout, at the core of the standard urban-rural integration model are "two types of industrial parks and two types of residential communities". The two types of industrial parks are (i) high-tech, finance or high-end manufacturing parks, and (ii) modern agricultural parks. The two types of residential communities are (i) apartment buildings and (ii) standalone single-household buildings or townhouses. The 
goal is to achieve intensive use of land and improve life quality of farmers.

(3) Property rights certification and development of diverse market entities

The government should put in place a certification system under which a certificate of title is issued to village-level collective organizations to prove their ownership of collective land and rights to use collective construction land. The village collective organizations can transfer their use right to the town-level joint venture through democratic procedures and thus become shareholders of the joint venture. The joint venture will join hands with private investors to set up a project company. The use rights of the construction land will be changed accordingly and the project company will hold a property ownership certificate of the project. The town-level joint venture may also lease land to private investors. The collective economic organizations within the built-up areas are encouraged to develop construction land for their own use, and the remaining profit after dividend payment should be included in collective assets and managed by the collective economic organizations.

(4) Bank loans and private capital

The property owner may pledge expected future income from property on collective land to financial institutions such as banks in order to get a loan, which reflects the market value of collective land. Collective organizations may also raise money from private sources to bring together high-quality intellectual capital and collective land. A financing system under which financial markets are the major sources of money whereas government funding is only a complementary source should be built.

(5) Optimization and standardization of quotas

The key to the implementation of floor area ratio bonus and transfer option policies is to standardize the allocation of collective construction land quotas and encourage intensive and standardized development of land at township and village levels. Construction land quotas can be controlled at the district level and coordinated at the township level. Balancing quotas may be used for cross-township projects. For example, one plot can be allocated for construction purpose for every five plots where property on which is demolished, or the government can set an adjustment coefficient and offer appropriate incentives. The design of quotas should be flexible, taking into account the uncertainty in the development of rural areas and the sheer size of undeveloped land in rural areas.

(6) Opening the market and leveling the playing field

A level playing field should be provided for all players to compete through clear, open and fair procedures and government intervention should be minimized. Basic criteria and requirements should be set to regulate investment companies in terms of equity ratio, industrial resources, registered capital, distribution of profits, and linkage of primary and secondary markets. The overall goal is to seek more efficient private sector partners through full and open competition.

(7) Equal rights to land and balanced development
It is very important to design a scientific and reasonable collective land profit distribution system to properly handle the relationship between collective economic organizations and the state as well as between collective economic organizations and farmers. In principle, the government is responsible for constructing the infrastructure; after charging a reasonable amount of service fee, the investment company should hand over the remaining profits to the township-level land management cooperative or joint venture, which will distribute the remaining profits to shareholders in proportion to their shareholding.

(8) Industrial upgrading

Township-level land planning should be aligned to the industrial positioning of the township. An industrial park developed without referring to the industrial positioning may sit empty after putting into operation. Policies should be introduced to support the development of themed towns and the "Beautiful Countryside" campaign. Building dismantling should be standardized. Non-core functions should be relocated. Green space should be planned appropriately. For example, the government may set up municipal- and district-level funds or provide subsidies to support the move of the growth pressure out of the core areas. Punishment should be doled out to entities which fail to meet their green space quotas. It is also a good idea to subsidize companies for eliminating backward production capacity. Measures should also be taken to increase the supply of collective rental housing.

\subsection{Establishment of a Modern Industrial Organization System for Agricultural Activities}

Similar to the embryo development process, the functions of an organization become more and more compound as they become increasingly specialized. It can be found generally at home and abroad that family farms focus on production, specialized cooperatives on distribution and marketing, and agricultural companies on processing. Collective economic organizations are entities unique to China. Properly defining their functions and role is the key to the establishment of a modern industrial organization system for agriculture.

First, collective economic organizations as property owners and operators have obvious advantages.

Collective economic organizations as property owners have many comparative advantages. [11] $66.60 \%$ of the surveyed farmers believe that the village-level collective organization is the most reliable property owner, compared to $12.41 \%$ who chose specialized cooperatives and $10.45 \%$ who chose leading enterprises. $36.50 \%$ of the surveyed village-level officials also chose the village-level collective organization, followed by leading enterprises and cooperatives.

The advantages of collective economic organizations as property operators are not as obvious as the advantages of collective economic organizations as property owners. The survey shows that $36.46 \%$ of the surveyed rural households believe that collective economic organizations are the most sustainable management entity, indicating farmers' strong confidence in them, compared to $26.90 \%$ who chose 
cooperatives, $20.71 \%$ who chose large-scale farms, and $15.93 \%$ who chose family-based management. Of course, collective economic organizations can indirectly engage in agricultural operations by creating specialized cooperatives. According to the survey, specialized cooperatives initiated by village-level collective economic organizations account for $38 \%$ of all specialized cooperatives; those initiated by farmers 34\%; those initiated by entrepreneurs or large farms $23 \%$; and those initiated by enterprises and agricultural departments $1 \%$ and $2 \%$, respectively. In addition, in case of land acquisition, members of the collective economic organization can jointly benefit from the compensation, thus preventing the outflow of interests.

Second, specialized cooperatives have done exceptionally well in providing distribution and marketing services and mobilizing farmers. First, specialized cooperatives offer diverse services. Among the specialized cooperatives surveyed, $66 \%$ primarily engage in production, processing and distribution activities, $23 \%$ in production, and $1 \%$ in transportation and distribution services. The surveyed rural households indicated that they joined specialized cooperatives or associations mainly to reduce production risks, sell goods at higher prices, receive technical training, and cut production costs and sale expenses. For example, Minong Renjia, an e-commerce company based in Miyun District, searches products for consumers, which is exactly the opposite of the traditional agricultural business model. Secondly, specialized cooperatives have played an increasingly important role in helping farmers increase income, brining significant social benefits. $19.78 \%$ of the surveyed rural households have joined a specialized cooperative, of which $41.45 \%$ said they were "satisfied" with the income brought by the specialized cooperative, and only $9.78 \%$ said they were "unsatisfactory". Among the surveyed rural households which have not joined a specialized cooperative, $64.77 \%$ expressed their willingness to join one. In 2012, 2014 and 2016, the surveyed specialized cooperatives helped 90, 112 and 163 households increase income, respectively.

Third, the government is the main supplier of public services which have strong externalities. According to the survey, $75.56 \%$ of rural families believe that the government provides the most effective technical training programs; $11.85 \%$ chose village-level collective organizations; $8.58 \%$ chose specialized cooperatives; and only $4.01 \%$ obtained technical training at their own expense.

Fourth, rural households are more effective when working as producers. According to the survey, $43.00 \%$ of the rural households joined a cooperative that engages in production activities by transferring land use rights, $37.37 \%$ sold products through specialized cooperatives, $54.55 \%$ were with cooperatives engaged in production activities, and $68.69 \%$ provide services for cooperatives.

In short, the differentiation of industrial organizations leads to the emergence of an integrated modern agricultural organization system under which collective economic organizations serve as property owners or operators, cooperatives, and agricultural enterprises primarily serve as operators, relevant government departments and new business entities are service providers and rural households are producers. (see Figure 6).

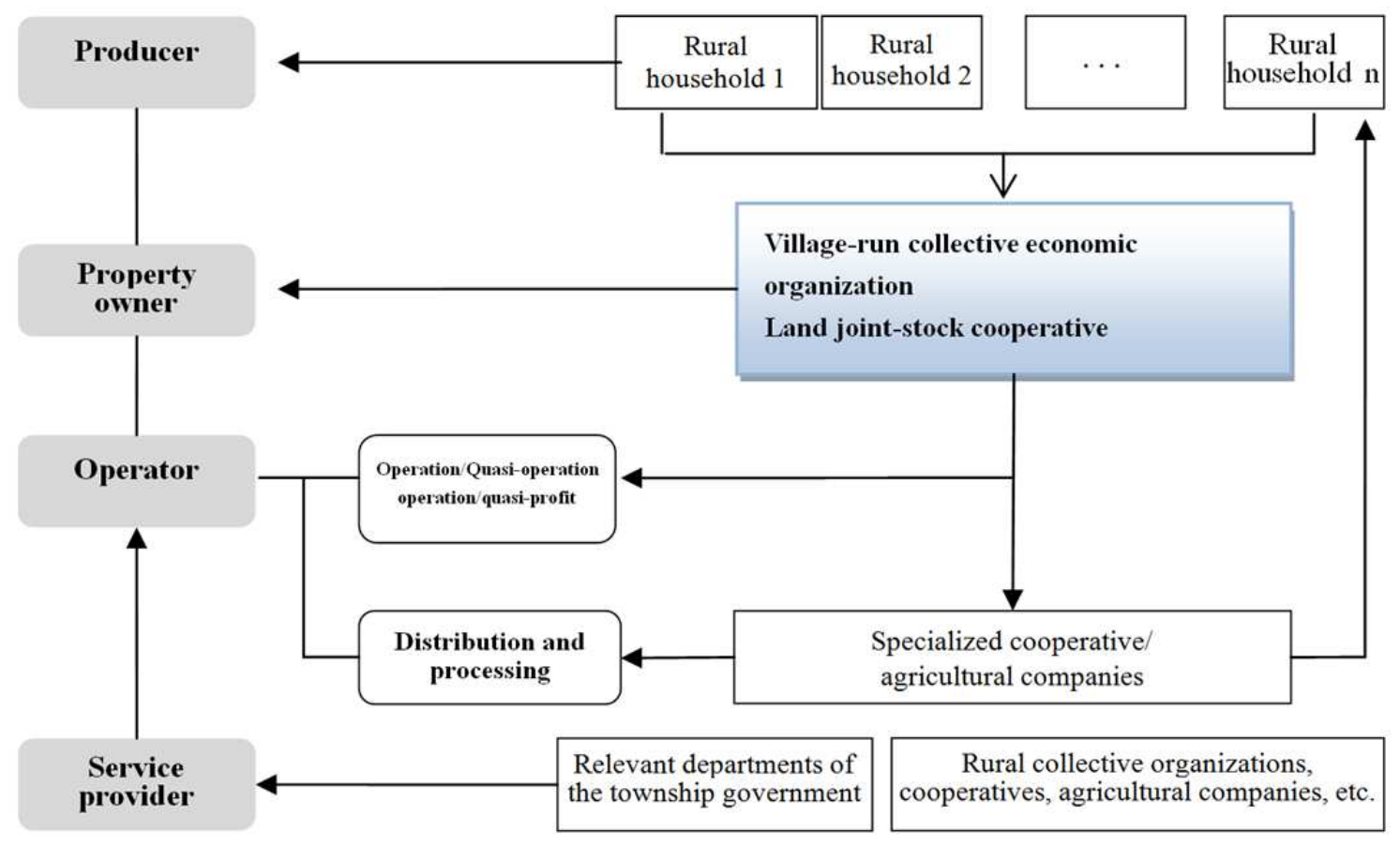

Figure 6. Functions of agricultural entities.

In practice, relevant authorities should focus on district-level planning, development of township and village-level entities, market-oriented operation, and social governance, make sure collective economic organizations effectively perform their functions, and strive to establish a well-functioning industrial organization system for the 
agriculture sector. The market-based industrial organization system for the agriculture sector is composed of three basic organizational forms established at the district, township and village levels, namely, village-level specialized organizations engaging in production activities, township-level agricultural companies, and industrial (specialized) associations at the district level, and is an effective combination of cooperatives, companies, and social organizations. Business entities such as specialized cooperatives and agricultural companies can gain comparative advantages through market-oriented operation. In a socialist market economy, these entities make up a three-tiered industrial organization system for agriculture that is suitable for Beijing.

(1) District-level planning

Relevant district-level government departments are responsible for the top-level design of the industrial organization system for agriculture, including agricultural industry plan, land use planning, and design of supporting mechanisms and policies. The suburbs in Beijing have created an umbrella brand for agricultural products unique to these areas and enlisted the help of Party committees and relevant government departments at the district level to build a systematic, efficient, networked agricultural operation system with social functions.

They are responsible for initiating district-level industry (specialized) associations based on product types. These associations are responsible for developing relevant technical standards, promoting the latest scientific and technological achievements, establishing an information platform, and pushing for preferential policies and regulations to support the development of the industry.

They are also responsible for technical services. They should set up technical training, quality inspection, industry information and other public service mechanisms for economic entities.

(2) Township and village-level entities

Township and village-level entities are responsible for implementing the functions of collective organizations. At the village level, collective economic organizations set up a specialized production organization to organize the production activities for certain type of product. Village-level collective economic organizations can lease land to such specialized production organizations. At the township level, an agricultural parent company and specialized companies are set up, procuring products from village-level entities. On one hand, town-level companies are responsible for post-production activities such as processing and sale of agricultural products. On the other hand, they are responsible for the centralized procurement and supply of means of agricultural production, promotion of technologies, and establishment of a regional agricultural public service system.

As the owner of collective land, the village-level collective economic organization is mainly responsible for the consolidation of land resources and the management of collective assets. It has the following rights:

Rights to hold and plan collective lands. The rural collective economic organization has the right to plan and develop land transferred to it. It is responsible for township-level land use planning, master planning, and village improvement planning.

Rights to transfer and adjust land use rights. The village-level collective economic organization has the right to transfer land use rights to or adjust land use rights in the hand of village-level land join-stock cooperatives as a means to consolidate fragmented land use rights and exploit the economies of scales. Collective economic organizations can join hands to build specialized groups (or teams) to exploit the economies of scales. In case of any of the following events, land use rights will be transferred to the village-level collective economic organization: (i) a rural household is willing to voluntarily transfer its land use rights to the village-level collective economic organization; (ii) large-scale family farms agree to exchange land plots, for which the collective economic organization should pay an agreed amount of compensation; (iii) a farmer willingly transfers land use rights for old age or other reasons, for which the collective economic organization should pay an agreed amount of compensation; (iv) a rural household is no longer a part of the village-level collective economic organization due to relocation or there is no living person on the hukou of the household, on which occasion the collective economic organization may directly acquire land allocated to the family.

Rights to benefits. Contractors must meet quotas and turn in the required amount of profits, after withdrawals to cover payment to the provident fund, public welfare funds and management fees, to the village-level collective organization or land joint stock cooperative which will distribute the profits among members. A transfer agreement is signed between the village-level collective organization and the operator, with collective assets as the subject matter or under which an incremental pricing mechanism is established.

Right to dispose. The village-level collective organization has the right to dispose of the land within its control as long as the contractors' rights are protected.

(3) Market-oriented operation

Competitive markets should play a decisive role in selecting, among others, suppliers of means of production and distributors and processors of agricultural products.

Cooperation. The village-level collective organization may establish cooperatives to operate land other than that for self-use, village collectives can lead the formation of cooperatives, or select efficient specialized cooperatives, agricultural enterprises and other business entities through open markets such as rural property rights exchanges to manage the land.

Corporate management. The village-level collective organization may establish specialized teams, companies or cooperatives and introduce standard management systems to improve the efficiency of assets management. Agricultural companies are encouraged to extend the value chain by engaging production, processing and distribution activities and realize whole-process standardized management.

Engagement of farmers. Farmers are encouraged to make good use of scattered time in the morning and evening to develop family farms, participate in the management of 
cooperatives or the collective organization or assume other responsibilities.

(4) Social governance

As the economic base determines the superstructure, the village-level collective organization helps farmers increase income and thereby enhances the cohesion within the collective organization.

It is necessary to put in place appropriate institutional mechanisms to support the coordinated development of entities. Property rights pooling, property rights transfer and other property rights tools should be leveraged to create a harmonious, symbiotic relationship between the collective economic organization and specialized farmers' cooperatives.

The collective economic organization should play a key role in connecting government departments, enterprises, cooperatives and farmers.

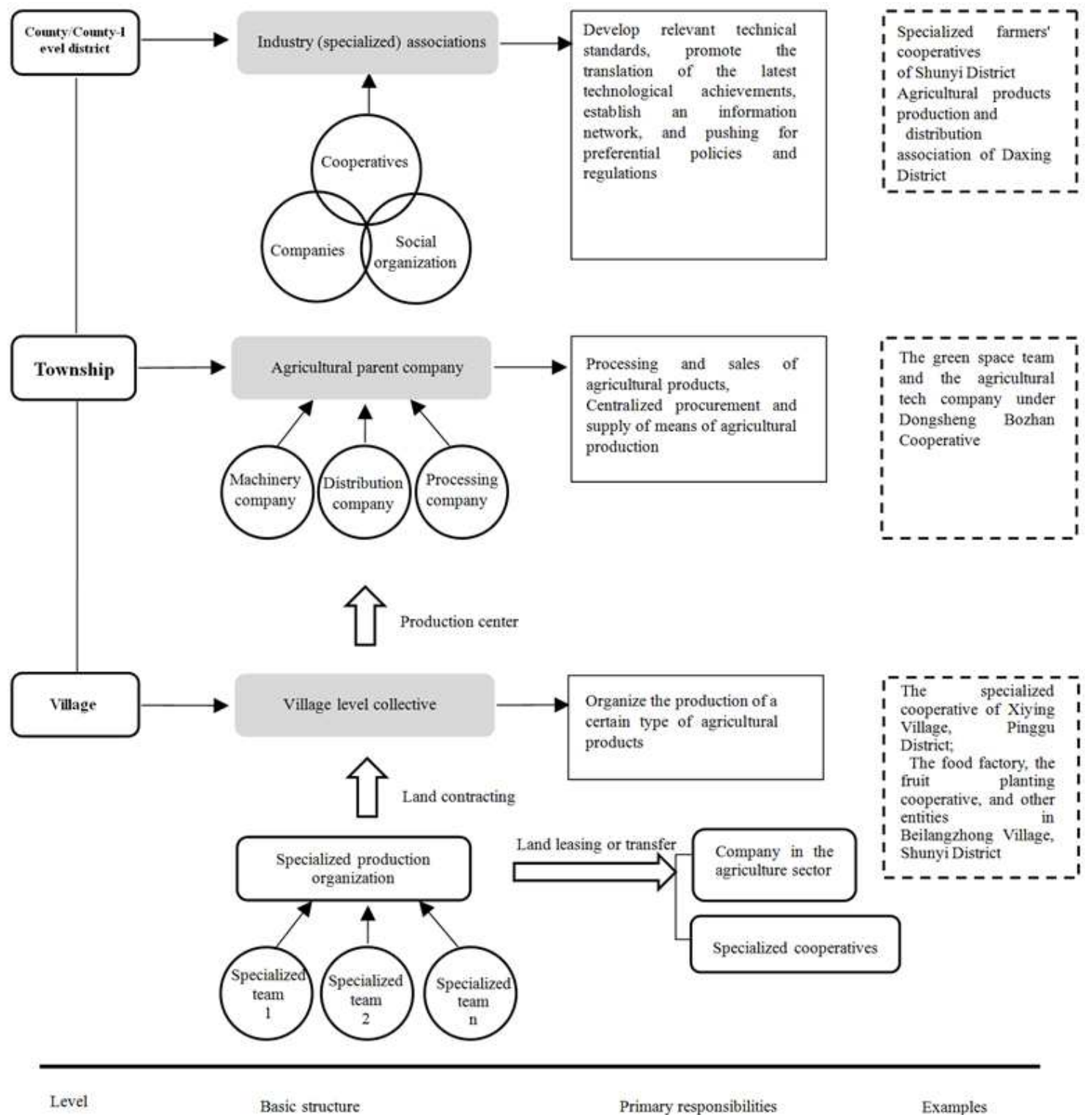

Figure 7. Structure of An agriculture industry revolved around the collective ownership of production means.

\subsection{Establishment a District-level Rural Collective Assets Supervision Commission}

In terms of functional positioning, the Rural Collective Assets Supervision Commission is an upgraded version of a current Economic and Management Station and is tasked with the responsibility of promoting balanced development in the sense of a district or county, strengthening supervision and facilitating market-oriented operation. It has social, administrative and commercial functions.
(1) Functional positioning

Social functions. The district-level Rural Collective Assets Supervision Commission is responsible for promoting balanced development of urban and rural areas and of different regions, supporting the development of collective economic organizations, enriching farmers in the course of urbanization, addressing issues of housing, social security and public services, driving localized urbanization, and facilitating the social restructuring in the suburbs.

Administrative function. The core administrative function 
is to strengthen the traditional functions of the economic management stations related to the management of collectively owned funds, assets, and resources and to increase the effectiveness of collective assets supervision. With the rapid growth of collective assets, the supervision and management of collective assets has become increasingly difficult, and its impact on the economy and society has also increased. For example, the township Economic and Management Station has the same administrative rank as that of a division or department. However, currently, township-level use of collective assets is managed by the township Party Committee and township government, which makes it difficult for the township Economic Management Station to manage township-owned collective assets. Relatively, the Collective Assets Supervision Commission has better functions and authority, adopts more efficient supervision methods, and expanded scope of supervision, and can effectively protect the rights of farmers.

Commercial functions. To adapt to the new stage of rural economic reform, it is necessary to build a new system at the district level to strengthen the management of rural collective assets. Through resource-regulation and allocation at the district level, the value of collective land resources will be maximized and promoted the balanced development of the township economy. In response to the absence of a collective land management system, a platform should be in place bringing together authorities of land planning, development and reform, and agricultural issues. In this way, the transition from the conversion of resources to assets, to asset management, to collective capital investment can be completed.

(2) District-level entities

Generally, one decision-making department and three functional departments are set up at the district level.

Decision-making department. The district-level collective assets supervision commission is responsible for coordinating the management of collective assets within the district. There is an office and a district-based parent company under it. It meets quarterly to decide on major issues such as policies, appointment and dismissal of personnel, and project selection.

Regulatory department. The office of the district-level collective assets supervision commission is responsible for supervising the management of collective assets on behalf of the commission. It is tasked with the responsibility of (i) supervising, assessing and offering guidance to rural collective economic organizations and rural collective companies; and (ii) developing collective asset management policies and regulations. In particular, it is necessary to speed up the development of the legislative framework, enhance the legal protection of rural collective economic organizations, and provide a legal basis for the nature, organizational principles, management system, property rights system, management structure, and profit distribution of rural collective economic organizations.

Operation department. The district-based parent company is wholly owned by the district-level collective assets supervision commission. It is primarily responsible for (i) relocating non-core functions of the city, promoting industrial upgrading, driving development of small towns, revamping old villages and industrial yards, constructing collective rental housing, improving the management of rural collective assets, etc.; and (ii) optimizing planned land use quotas in collaboration with other departments to promote balanced urban-rural development within the district. The company has a rural development fund which mainly invests in rural reform pilot areas and supports the relocation of non-core functions of Beijing City, upgrading of high-tech and cultural industries and some livelihood and environmental improvement projects. The focus of the company is to fund building demolition, land consolidation, resettlement of residents, etc. The company also features a rural property rights trading platform (equivalent to the deputy division level) which is mainly responsible for collective land equity transactions, collective land transfer, and index swapping.

Social organization. A special social organization should be created to serve the collective economy. The district-level collective assets supervision commission should establish collective organizations such as collective land federations, collective economic federations (similar to the federation of industry and commerce) or the collective economic promotion association to serve rural collective economic organizations. The staffing of such social organizations may be included in the staffing plan of public institutions.

\section{Conclusion}

To sum up, this paper explains the regularity of the evolution of rural collective economic system, and accordingly puts forward that the reform of overall planning of villages and towns is the only way to implement the strategy of rural revitalization. There are three concretely conclusions:

(1) From the perspective of the evolution of economic system, township planning is a new economic system following the household contract management system for 'integration of unification and division, and double-level operation', people's communes, and is a key stage of the transformation from agricultural society to industrial society through village collective economic group. The joint venture among village-level collective economic organizations will reconnect the fragmented land property rights, realize the centralized and optimized allocation of land resources, and promote the balanced and coordinated development of urban and rural areas and regions.

(2) From the point of view of collective land reform, town and township co-ordination is a new land system, which can be called "joint land system". Unlike most land reform in the world, such as average land ownership and "single tax", which focuses on income distribution, town and township co-ordinated land reform is a socialist land based on public ownership, which not only solves the problem of land sharing, but also realizes the best use of land. This is the fundamental 
way to increase village wealth.

(3) From the perspective of urbanization, the overall planning of towns and townships is transformed from urbanization mode driven by big cities to local urbanization. [12] Let farmers "bring capital into the city", crossing the high cost threshold of citizenization, improve the quality of citizenization, and realize the steady transformation of economy and society. [13-15] Therefore, the original meaning of town-and-town co-ordination can be summarized as follows: through the establishment of township-level property rights subject, cross-village joint venture, breaking through the system pattern of "village self-struggle", Intensively utilizing collective land, integrating collective resources, assets and funds, and realizing the sharing of land and land to the best of their interests, it is a new kind of transformation of social structure for farmers.

\section{References}

[1] Xi Jinping, "To Win the Great Victory of Socialism with Chinese Characteristics in the New Era by Building a Well-off Society in an All-round Way: A Report at the Nineteenth National Congress of the Communist Party of China "(18 October 2017), People's Publishing House, the $1^{\text {st }}$ edition in October, 2017.

[2] Xi Jinping," Poverty Alleviation Should Pay Attention to Enhancing the Collective Economic Strength at the Rural Level" (April 1999), Getting Out of Poverty, PP. 193-194, Fujian People's Publishing House, the $1^{\text {st }}$ edition in July, 1992.

[3] Xi Jinping, Research on the Construction of Rural Marketization in China, pp. 386, People's Publishing House, the $1^{\text {st }}$ eition in July, 2001.

[4] Beijing Rural Economic Research Center, Part of Xi Jinping's Exposition on Several Issues of Collective Economy (Discussion Draft), January, 2018.
[5] Mao Zedong, The Chinese Revolution and the Communist Party of China, quoted from Volume II of Selected Works of Mao Zedong, People's Publishing House, the $2^{\text {nd }}$ edition in June, 1991.

[6] Chen Xueyuan, Township Planning, February 2018, the first edition of China Social Science Press.

[7] Chen Xueyuan, On Village Wealth: A Survey of 40 Villages in Beijing Suburbs from 1978 to 2006, June 2016, the first edition of China Finance and Economics Press.

[8] Chen Xueyuan, Wang Hongyu: "New Collective Economic Organizations: The Successful Code of Tangyue Road - Basic Types and Future Trends of Rural Economic System Evolution", China Economic and Trade Guide, June 2017.

[9] Guo Guanglei, Chen Xueyuan: "Thoughts on Township Coordination Reform and Urbanization Transition - Based on the Typical Experience of the Rural Collective Land Reform Pilot Project in Daxing District”. Financial Think Tank, Vol. 2, No. 3, 2017.

[10] Guo Guanglei. Thoughts on the new-style urbanization and intensive use of collectively-owned land for construction in Beijing. China Economic and Trade Herald, 2015.21.

[11] Subject Group of Beijing Rural Economic Research Center, Research Report on New Agricultural Management System in Suburbs of Beijing, 2017.9.

[12] Lewis, W. A.: Economic Development with Unlimited Supplies of Labor, 1954. The Manchester School of Economic and Social Studies. Selected Economic Writings of W. Arthur Lewis, edited by Mark Gersoviz, 1983. New York University Press.

[13] Chen Xueyuan. On hypothesis and empirical study of Lewis Model. Chinese Rural Economy, 2015.3.

[14] Wei Houkai and Chen Xueyuan. "Overcoming the difficulty of the urbanization of rural residents by letting rural residents bring assets to the city." China Economic and Trade Guide, no. 4, 2012.

[15] Buchanan, James M. Property as a Guarantor of Liberty. Trans. Han Xu. Beijing: China Social Sciences Press, 2002.1. 